\title{
Ten Million Colony Forming Units
}

National Cancer Institute

\section{Source}

National Cancer Institute. Ten Million Colony Forming Units. NCI Thesaurus. Code C158294.

A unit of measurement of viable bacterial numbers equal to 10 to the seventh power colony forming units. 